Check for updates

New York

Cite this as: BMJ 2021;375:n2558 http://dx.doi.org/10.1136/bmj.n2558 Published: 19 October 2021

\title{
Covid-19: US cases drop overall but increase among children
}

\section{Janice Hopkins Tanne}

Hospital admissions for covid-19 among children aged 5-11, who are not yet eligible for vaccination, have reached an all time high in the US, with 1.1 hospital admissions per 100 ooo for the week ending 25 September, according to the Centers for Disease Control and Prevention. ${ }^{1}$

Overall, however, cases are falling, with a daily average of about 86600 , down from around 15000 a month ago. Daily deaths were around 1500, down from nearly 2000 a month ago. ${ }^{2}$

There were 1.1 million cases of covid recorded in children in the past six weeks with children making up $25.5 \%$ of new cases, according to the American Academy of Paediatrics. ${ }^{3}$ Although cases have reduced from a peak of 252000 in the week of 2 September to 131 ooo in the week ending 14 October, the academy described the current number as "extremely high."

So far, the US has reported nearly 45 million infections and 725000 deaths, by far the highest in the world. ${ }^{2}$

Pfizer has asked the Food and Drug Administration (FDA) for emergency use authorisation for the Pfizer BioNTech vaccine for children aged 5-11.

President Joe Biden and Anthony Fauci, director of the National Institute for Allergy and Infectious Diseases, among other experts, have stressed that widespread vaccination is the way out of the pandemic. Some $57 \%$ of the US population is fully vaccinated. Vaccination rates range, however, from a high of $70 \%$ in the north eastern states of Connecticut, Maine, Rhode Island, and Vermont to a low of $41 \%$ in West Virginia. ${ }^{2}$

The FDA has approved booster shots for those who had the Pfizer vaccine and is expected to do the same for the Moderna and the Johnson and Johnson vaccines.

Data published on 15 October showed dramatic differences in illness and death between the unvaccinated and vaccinated. Unvaccinated people were much more likely to test positive for covid-19 and 11 times more likely to die. ${ }^{4}$

President Biden called for employers with 100 or more employees to make sure their employees were either vaccinated or were tested every week for covid-19.

Vaccination rates have increased as companies, hospitals and healthcare facilities, universities, and other institutions have required vaccination as a condition of employment. In some cases, either proof of vaccination or weekly covid-19 testing is required.

Governor Greg Abbott of Texas banned any entity in his state from mandating vaccines. ${ }^{5}$ These mandates have met resistance, with employees quitting or joining large protests. Despite the governor's mandate, Southwest Airlines, headquartered in Dallas, required its employees to be vaccinated if they wanted to keep their jobs. Hundreds of the airlines employees and customers rallied outside its Dallas offices on 18 October. American Airlines, headquartered in nearby Fort Worth, faced a similar protest on 7 October with employees claiming that their freedom was being denied. ${ }^{6}$

Resistance to mandates and the vaccine have also led to distrust in public health authorities and anger, according to a national survey conducted by the New York Times, which contacted hundreds of public health departments in all 50 states.

Tthe Times reported "a staggering exodus" of public health personnel who were exhausted and demoralised by abuse and threats. More than 100 new laws-like Abbott's in Texas-have limited the powers of state and local health authorities.

"Large segments of the public have also turned against agencies, voting in new local government leaders who ran on pledges to rein in public health departments," the Times said. It also reported that although the federal government has given billions of dollars to public health agencies, most of the funds have been spent on dealing with the emergency rather than on hiring permanent staff and building strong agencies for the future. ${ }^{7}$ review: interpretive summary for October 15, 2021. www.cdc.gov/coronavirus/2019-ncov/covid-data/covidview/index.html.

2 Coronavirus in the US. Latest map and case count. New York Times. 18 October 2021. www.nytimes.com/interactive/2021/us/covid-cases.html.

American Academy of Pediatrics. Children and covid-19: state-level data report. October 2021. www.aap.org/en/pages/2019-novel-coronaviruscovid-19-infections/children-and-covid-19-state-level-data-report.

4 Centers for Disease Control and Prevention. Covid data tracker: covid-19 cases and deaths by vaccination status. 15 October 2021. https://covid.cdc.gov/covid-data-tracker/\#rates-by-vaccine-status.

5 Jeong A. Texas Gov Greg Abbott bans coronavirus mandates, including for private business. Washington Post. 12 October 2021. www.washingtonpost.com/nation/2021/10/12/greg-abbott-bans-vaccine-mandate.

6 Arnold K. Hundreds rally at Southwest Airlines headquarters against employee vaccine mandates. Dallas Morning News. 18 October 2021. www.dallasnews.com/business/airlines/2021/10/18/hundreds-rally-atsouthwest-airlines-headquarters-against-employee-vaccine-mandates.

7 Baker M, Ivory D. Public health crisis grows with distrust and threats. New York Times. 18 October 2021. https://static01.nyt.com/images/2021/10/18/nytfrontpage/scan.pdf.

This article is made freely available for use in accordance with BMJ's website terms and conditions for the duration of the covid-19 pandemic or until otherwise determined by BMJ. You may use, download and print the article for any lawful, non-commercial purpose (including text and data mining) provided that all copyright notices and trade marks are retained. 